\title{
Fritaksrett og presiseringer om religionsundervisning også i videregående opplæring?
}

Bengt-Ove ANDreassen, Ph.D. førsteamanuensis, Institutt for lererutdanning og pedagogikk (ILP), UiT - Norges arktiske universitet. E-post: bengt.ove.andreassen@uit.no

I dag er ikke fritak fra undervisning noe som er nevnt i kapittelet om videregående opplæring i opplæringsloven. Her er fokuset utelukkende på retten til opplæring. Denne refleksjonsartikkelen reiser spørsmålet om opplæringslovens kapittel om videregående opplæring trenger en paragraf om fritaksrett, samt presiseringer om religionsundervisningen, slik det finnes for grunnskolen. Artikkelen presenterer noen refleksjoner over dette, og diskuterer med henvisning til endringer i lovverket for grunnskolen som har kommet som et resultat av debatt og kritikk av KRL-faget.

\section{FRITAKSRETTEN I GRUNNSKOLEN ETTER 1997}

Fritaksretten i grunnskolen var først noe som kun gjaldt for undervisningen i KRL, men i 2005 ble en egen paragraf skilt ut $-\$ 2-3 a-$ for å tydeliggjøre at fritaksretten gjaldt hele grunnskoleopplæringen (jf. KRL-boka 2005: 27). Siden da har fritaksretten handlet om aktiviteter generelt i skolen, og ikke bare om religionsundervisningen. Fritaksordningene knyttet til religionsfaget i grunnskolen har vært gjenstand for het debatt, og flere endringer er gjort siden innføringen av KRLfaget i 1997. I forkant av innføringen vakte en begrenset mulighet for fritak i faget harme og engasjement blant foreldre og religions- og livssynsminoritetene. Når det ikke ble åpnet for en mulighet for fullt fritak fra undervisningen i KRL, førte det til en prinsipiell debatt om religionsfrihet og forholdet til Norges folkerettslige forpliktelser (jf. f.eks. Høstmælingen (red.) 1998, 2004).

Kirke-, undervisnings- og forskningsdepartementet (KUF) var trolig klar over at et obligatorisk religionsfag med en begrenset fritaksrett kom til å vekke reaksjoner allerede ved innføringen av KRL-faget. I forkant av fagets innføring i skolen ble dette debattert og behandlet i Stortinget og i departement i flere runder. Det resulterte i at KUF bad lagdommer Erik Møse foreta en gjennomgang av sakens juridiske sider med tanke på forholdet mellom grunnskolens daværende kristne formålsparagraf og Norges forpliktelser til internasjonale konvensjoner (Ot.prp. nr. 38 (1996-97)). I sin utredning anbefalte Møse ([1997] 1998: 203): "Slik situasjonen nå framstår, finner jeg at det tryggeste er en generell fritaksrett". Etter behandling i Stortinget våren 2001 (St. meld. Nr. 32 (2000-2001)) ble det sendt ut informasjon til skoler, foreldre og foresatte med presiseringer om fritaksretten. Her ble det slått fast at KRL-faget fremdeles var et obligatorisk fag, men at en begrenset fritaksrett var opprettholdt. Det ble i denne forbindelse også utarbeidet et eget 
skjema (på flere språk) for å gjøre fritaksretten lettere å benytte seg av (jf. KRL-boka 2002: 53-55).

Spørsmålet om en fritaksrett i videregående skole ble ikke drøftet av Møse eller i den politiske behandlingen av ordningen for grunnskolen, selv om det fra 1998 ble vedtatt en felles opplæringslov for både grunnskole og videregående opplæring.

Siden 2005 har altså fritaksretten $(\$ 2-3 a$ Fritak frå aktivitetar m.m. i oppleringa) vært en rettighet som gjelder aktiviteter i skolen generelt, og ikke bare noe som omhandler undervisningen i grunnskolens religionsfag. Fra 2008 er det gjort ytterligere endringer i opplæringsloven for å forenkle bruken av denne rettigheten. Nå trenger foreldre og elever over 15 år kun å gi skriftlig melding om fritak (se Rundskriv F-10-08). Det er ikke nødvendig å bruke noe spesielt skjema, og det er heller ikke nødvendig å søke om fritak. Det kreves heller ikke begrunnelse for melding om fritak. Fritaksordningen sikrer tydelig foreldre eller foresatte (og elever som har fylt 15 år) å gjøre en subjektiv vurdering om hva de opplever som tilslutning til en religion, religionsutøvelse, eller som krenkende eller støtende.

En viktig side ved fritaksretten er at det ikke gis fritak fra kunnskapsinnholdet i de emnene det undervises i, uansett fag. Det kan ikke meldes om fritak i RLE-faget fordi temaet er hinduisme, islam eller religionskritikk, eller i samfunnsfag fordi temaet er kjønn og likestilling. Dette er emner som elevene skal lære om.

Fritaksordningen skal sikre at elevers og foreldres religiøse og filosofiske overbevisninger ikke krenkes. Ordningen gjenspeiler de folkerettslige konvensjonene som den norske stat har forpliktet seg til og som er inkorporert i norsk lovgiving (jf. Lov om styrking av menneskerettighetenes stilling i norsk rett (men- neskerettsloven)). Endringene i opplæringsloven i 2005 og 2008 var direkte resultat av kritikken fra FNs Menneskerettighetskomite i 2004 og Den europeiske menneskerettighetsdomstolen i Strasbourg (EMD) i 2007 (se Andreassen 2012: 65-68). I sakene som ble lagt fram for disse to instansene, ble ikke videregående opplæring nevnt, og var følgelig ikke en del av deres uttalelser.

I et felles og integrerende religionsfag bør det være et poeng at alle elever er til stede til enhver tid. Undervisningen bør derfor legges opp slik at det i liten grad er aktiviteter som kan oppfattes som problematiske for foreldre og elever. Tydelige religiøse aktiviteter bør unngås. Det gjelder for eksempel bønn, salmesang og gudstjenester/andakter, eller gjennomføring av ulike religiøse ritualer i klasserommet. I $\ 2-4$ om undervisningen i RLE i grunnskolen gjøres eksplisitte formuleringer angående dette, mens slike presiseringer ikke er til stede i læreplanen for Religion og etikk i videregående skole eller i kapittel 3 av opplæringsloven. I et skriv fra Utdanningsdirektoratet i 2009 (Udir 2009) om gudstjenester i skoletiden presiseres det at gudstjenester ikke kan være en del av RLE-faget, og at gudstjenester ikke bør være siste felles aktivitet som semesteravslutning. Heller ikke her nevnes videregående opplæring.

\section{RETT TIL FRITAK - IKKE BARE RETT TIL OPPLÆRING?}

Den norske stats folkerettslige forpliktelser synes å være helt fraværende i den delen av opplæringsloven som omhandler videregående opplæring. Med tanke på den betydelige oppmerksomheten disse prinsipielle sidene har fått $\mathrm{i}$ grunnskolen, er det påfallende at de ikke nevnes med et eneste ord i det juri- 
diske rammeverket for videregående opplæring. Der kapittel 2 i opplæringsloven om grunnskolen inkluderer $\$ 2$-3a om fritak og endog en egen paragraf (\$2-4) om religionsundervisningen, har kapittel 3 om videregående opplæring, ingen slike paragrafer. Her er fokuset utelukkende på retten til videregående opplæring.

På prinsipiell basis er det nærliggende å tenke at de samme grunnene for fritak som det åpnes for i \ 2-3a, også kan være til stede i videregående opplæring. Det handler ikke om at elevene på tredje år i videregående opplæring fyller 18 år (før eller) i løpet av skoleåret. Fritaksretten åpner for at elever som er fylt 15 år skal kunne gi melding om fritak selv. Når de er fylt 18 år og holder på med videregående opplæring, er det et paradoks at denne rettigheten forsvinner. Særlig med tanke på at innholdet og omfanget av videregående opplæring er regulert av norsk lov (med tilhørende forskrift). Det er nærliggende å tenke at dette lovverket skulle være mer eksplisitt når det gjelder ivaretakelsen av grunnleggende folkerettslige rettigheter.

Heller ikke om undervisningen i Religion og etikk gjøres det presiseringer, slik vi finner i $\$$ 2-4. Her presiseres det at RLE-faget ikke skal være forkynnende. Og videre, at undervisningen skal behandle «ulike verdsreligionar og livssyn på ein objektiv, kritisk og pluralistisk måte». Slike presiseringer fra kapittel 2 av opplæringsloven kunne også vært viktige prinsipper for undervisningen i Religion og etikk i videregående skole. Det ville bidra med å avklare hvordan faget skal forstås. Det ville være relevant med en avklaring fra Kunnskapsdepartementet og Utdanningsdirektoratet hvorfor dette er viktige presiseringer og rettigheter i grunnskolen, men ikke i videregående opplæring.

En forklaring ligger muligens i at videre- gående opplæring ikke er obligatorisk, slik grunnskolen er det. De elevene som velger å benytte seg av retten til videregående opplæring, velger det i prinsippet selv. Ikke desto mindre er Religion og etikk et fellesfag, og dermed obligatorisk, for elever som velger studiespesialiserende utdanningsprogram. Samtidig er videregående opplæring et tilbud som gis av den norske stat, og det er derfor nærliggende å tenke at lovverket for dette tilbudet skulle være mer åpent for å reflektere statens folkerettslige forpliktelser, og ivareta grunnleggende rettigheter på dette området. Det er prinsipielt problematisk dersom det er slik at å benytte seg av en rettighet på et område automatisk fører til at elever mister en på et annet.

\section{AVSLUTTENDE SPØRSMÅL}

Når jeg reiser spørsmålet om en mulig fritaksrett også i videregående opplæring, er det på bakgrunn av det vakuum som eksisterer i opplæringsloven på dette området. Fra å være en egen paragraf i kapittel 2 om grunnskolen, utarbeidet i lys av den norske stats folkerettslige forpliktelser, til å være helt utelatt i kapittel 3 om videregående opplæring. For elever på studiespesialiserende utdanningsprogram er Religion og etikk et obligatorisk fag. Det er et paradoks om dette skulle være rettigheter som den enkelte elev mister dersom han/ hun velger å ta videregående opplæring. De folkerettslige prinsippene den norske stat har forpliktet seg til, bør da gjelde i det offentlige utdanningssystemet, uansett om det er grunnskole eller videregående opplæring?

Det samme gjelder prinsipielle føringer for religionsundervisningen. I seg selv er det et paradoks at RLE-faget omtales i en egen paragraf. Når det like fullt gjøres, er det nærliggende å tenke at det kunne være behov 
for lignende presiseringer for religionsfaget i videregående opplæring. At det ikke skal være forkynnende, men en objektiv, kritisk og pluralistisk framstilling av religioner og livssyn. Noen slike presiseringer i kapittel 3 av opplæringsloven ville være avklarende for hvordan religionsfaget i videregånde opplæring skulle forstås.

\section{REFERANSER}

Andreassen, B.-O. 2012. Religionsdidaktikk. En innføring. Oslo: Universitetsforlaget.

Høstmælingen, N. (red.) 1998. Livssyns- og trosfrihet $i$ et menneskerettighetsperspektiv. Sarlig om faget kristendomskunnskap med religions- og livssynsorientering. Oslo: Juristforbundets forlag AS.

Høstmælingen, N. 2004. The Teaching of Religion in Primary and Secondary Schools in Norway. I: Lødrup, P. and Modvar, E. (red.): Family Life and Human Rights, s. 291304. Oslo: Gyldendal akademisk.

Møse, E. [1997] 1998. Fritak for undervisning i faget kristendomskunnskap med religionsog livssynsorientering. Forholdet til Norges folkerettslige forpliktelser. I Høstmælingen, N. (red.), Livssyns- og trosfrihet $i$ et menneskerettighetsperspektiv. Sarlig om faget kristendomskunnskap med religions- og livssynsorientering, s. 123-211. Oslo: Juristforbundets forlag AS.

Ot.prp. nr. 38 1996-97. Om lov om endringar i lov 13. juni 1969 nr. 24 om grunnskolen m.m.

Rundskriv F-15-07. Informasjon om endringer $i$ opplceringen i faget Kristendoms-, religionsog livssynskunnskap og om rett til fritak fra opplering i skoleåret 2007/2008. Oslo: Kunnskapsdepartementet.

Rundskriv F-10-08. Informasjon om endringer $i$ oppleringsloven. Oslo: Kunnskapsdepartementet.

St. meld. Nr. 32 2000-2001. Evaluering av faget Kristendomskunnskap med religions- og livssynsorientering.

Utdanningsdirektoratet. 2002. KRL-boka 2002. Oslo: Utdanningsdirektoratet.

Utdanningsdirektoratet. 2005. KRL-boka 2005. Oslo: Utdanningsdirektoratet.

Utdanningsdirektoratet. 2009. Gudstjenester i skoletiden. Skriv datert 9.11.2009. Oslo: Utdanningsdirektoratet. 